\title{
Structure and conformational analysis of spiroketals from 6-O-methyl-9(E)-hydroxyiminoerythronolide $A$
}

\author{
Ana Čikoš ${ }^{* 1}$, Irena Ćaleta ${ }^{1}$, Dinko Žiher ${ }^{1}$, Mark B. Vine ${ }^{2}$, Ivaylo J. Elenkov ${ }^{1}$, \\ Marko Dukši ${ }^{1}$, Dubravka Gembarovski ${ }^{1}$, Marina llijaš ${ }^{1}$, Snježana Dragojević ${ }^{1}$, \\ Ivica Malnar ${ }^{1}$ and Sulejman Alihodžić ${ }^{1}$
}

\section{Full Research Paper}

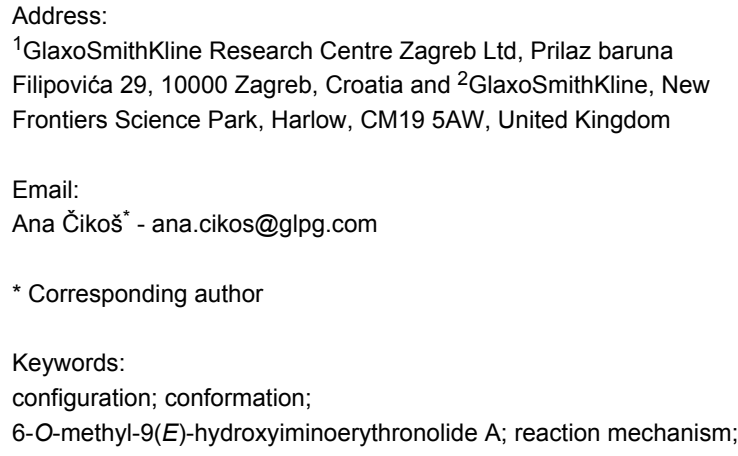

${ }^{1}$ GlaxoSmithKline Research Centre Zagreb Ltd, Prilaz baruna Filipovića 29, 10000 Zagreb, Croatia and ${ }^{2}$ GlaxoSmithKline, New Frontiers Science Park, Harlow, CM19 5AW, United Kingdom

Email:

Ana Čikoš ${ }^{*}$-ana.cikos@glpg.com

* Corresponding author

Keywords:

configuration; conformation;

6-O-methyl-9(E)-hydroxyiminoerythronolide $\mathrm{A}$; reaction mechanism; spiroketal

\author{
Beilstein J. Org. Chem. 2015, 11, 1447-1457. \\ doi:10.3762/bjoc.11.157 \\ Received: 13 April 2015 \\ Accepted: 23 July 2015 \\ Published: 19 August 2015 \\ Associate Editor: P. R. Schreiner \\ (C) 2015 Čikoš et al; licensee Beilstein-Institut. \\ License and terms: see end of document.
}

\begin{abstract}
Three novel spiroketals were prepared by a one-pot transformation of 6- $O$-methyl-9(E)-hydroxyiminoerythronolide A. We present the formation of a [4.5] spiroketal moiety within the macrolide lactone ring, but also the unexpected formation of a 10-C=11-C double bond and spontaneous change of stereochemistry at position 8-C. As a result, a thermodynamically stable structure was obtained. The structures of two new diastereomeric, unsaturated spiroketals, their configurations and conformations, were determined by means of NMR spectroscopy and molecular modelling. The reaction kinetics and mechanistic aspects of this transformation are discussed. These rearrangements provide a facile synthesis of novel macrolide scaffolds.
\end{abstract}

\section{Introduction}

Macrolide antibiotics are natural or semi-synthetic products of polyketide origin, containing one or more desoxy sugars attached to a macrocyclic lactone aglycon. This large and structurally diverse category of compounds has traditionally been divided into classes based on the aglycon size, principally 12-, 14-, or 16-membered ring macrolides [1]. The most extensively explored naturally occurring 14-membered macrolide erythromycin A was discovered more than 50 years ago. Subsequently it has become the focus of numerous structural modifications, with the primary aim of increasing its antibacterial spectrum, acid stability, masking the foul taste, improving the pharmacodynamic properties and reducing the associated side effects. The two most successful semisynthetic macrolide antibiotics derived from erythromycin A are azithromycin [2,3] and clarithromycin [4]. Recent investigations have shown that beside their antibacterial activity, some macrolides exhibit anti-inflammatory/immunomodulatory [5-10], antitumor [11-13], antiviral [10] or antimalarial $[14,15]$ activity. These discoveries have 
sparked a new interest in the structural modification of macrolides.

As a structural subunit, spiroketal ring systems $[16,17]$ are present in a wide range of natural compounds. Their rigidity makes them useful for conformational control in heterocycles, but also for stabilizing a highly specific conformation within otherwise flexible larger natural compounds. For example, in cases of calyculin and okadaic acid it has been proposed $[18,19]$ that the spiroketal unit acts as a $\beta$-turn mimic.

Naturally occurring spiroketals exhibit a wide spectrum of biological activity: anticancer [20-22], antibiotic [23,24], antifungal [25], anthelmintic [26] and anti-HIV [27]. A previously mentioned example of a protein phosphatase inhibitor okadaic acid is a toxin associated with diarrheic shellfish poisoning [28] Another example are structurally complex tubulin polymerization-inhibiting macrolides such as spongistatins, a family of compounds isolated from marine sponges, which display extraordinary antitumor activity [29]. At the same time, the spiroketal-containing integramycin acts as an HIV-1 protease inhibitor [27].

The studies of Hayashi et al. have shown that the integrity of the spiroketal subunit is essential for the inhibition of telomerase by rubromycins [30] and it seems that simplified but characteristic spiroketals derived from the parent natural products can retain biological activity [31]. Therefore, the spiroketal unit can be regarded as a biologically validated framework and having a macrolide with spiroketal moiety can lead to new compounds with potentially interesting biological profiles.

\section{Results and Discussion}

For several decades now, our continuing primary interest lay in 14-membered macrolides and their semi-synthetic 15-membered derivatives targeting therapeutic areas of bacterial [32-34] and parasitic [35] infections, as well as inflammation [36-38]. In the search for novel scaffolds to be used as a fresh starting point for further derivatisation [39], we explored modifications to the macrocyclic ring. Oxidative deoximation of $\mathbf{1}$ in mild acidic media, shown in Scheme 1, led us to an unexpected macrolide-spiroketal 2 which sparked our interest, not only because the spiroketal is a biologically relevant subunit whose incorporation into macrolide could yield interesting biological activity, but also because this unit provides unique rigidity to the 6-C to $12-\mathrm{C}$ region of the macrocycle allowing for specific orientations of the functional groups.

The spiroketal unit in erythromycin derivatives is not unknown in the literature, though. As the principal product of erythromycin A acid degradation, anhydroerythromycin A has been studied $[40,41]$ since erythromycin A started being used in human medicine as an antibiotic. This 14-membered macrolide contains a [4.4] spiroketal unit connecting 6-C-O-9-C-O-12-C. Stereochemistry at position 9-C of this spiroketal was determined by combination of NMR spectroscopy and molecular modelling [42]. The kinetics of its formation has also been extensively studied [43-46]. Most recently, in the latest revision of the reaction pathway Hassanzadeh et al. showed that this macrolide spiroketal in acid media exists in equilibrium with the 9,12-hemiacetal of erythromycin A [47]. The closely related antibiotic clarithromycin (structurally related to our starting aglycon 1) in acid medium does not degrade to the spiroketal but instead loses the cladinose sugar $[48,49]$. The degradation process terminates with decladinosyl clarithromycin in equilibrium with the 9,12-hemiacetal decladinosyl clarithromycin [50].

Unlike the acid degradation product anhydroerythromycin A, the spiroketal 2 exhibits the much less common [4.5]spiroketal unit connecting 5-C-O-9-C-O-12-C; its existence is made possible by the free $5-\mathrm{OH}$ functionality of the starting aglycon 1 $[39,51]$. Native macrolide aglycons are rarely found in nature [52], most likely because they are quickly glycosylated even before macrolactonisation [53]. The [4.5]ring system identified in the spiroketal 2 has been rarely explored in the literature: one example being the corresponding derivative of erythronolide $\mathrm{B}$ [54] unexpectedly formed during the acid-catalysed removal of a 3,5-acetonide protecting group, with the structure and stereo-

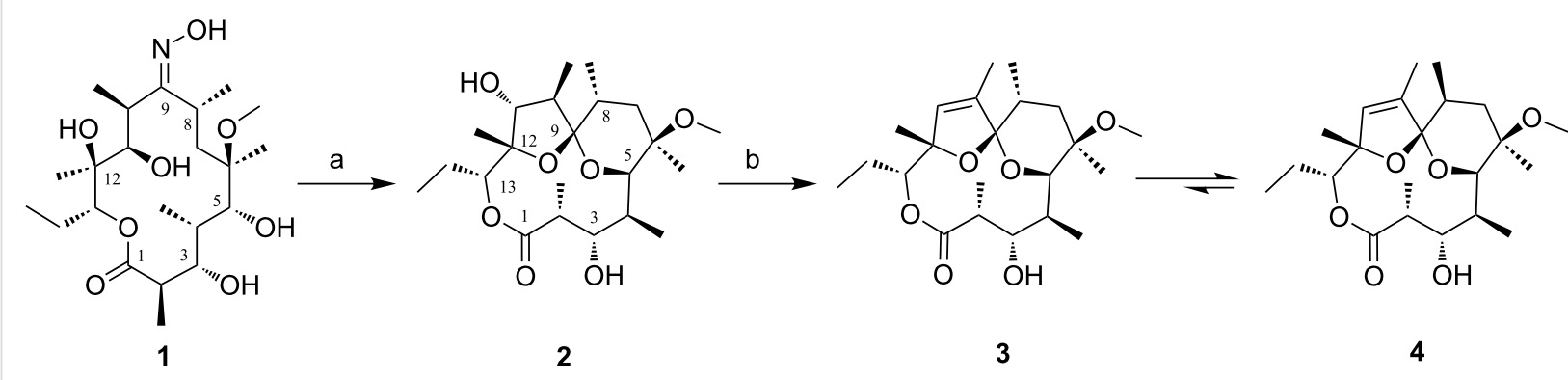

Scheme 1: Synthetic route to spiroketals 2-4. Reaction conditions: a) $\mathrm{Na}_{2} \mathrm{~S}_{2} \mathrm{O}_{5} / \mathrm{HCOOH} / \mathrm{EtOH} /$ water/70 $\left.{ }^{\circ} \mathrm{C}, \mathrm{b}\right) \mathrm{DCl} / \mathrm{CDCl} 3 / \mathrm{rt}$. 
chemistry confirmed by X-ray crystallography. The two others were obtained during a total synthesis of erythronolide $\mathrm{Al}$ $[55,56]$, as a result of deprotection of the 3,5-benzylidene acetal of erythronolide A (with or without a triethylsilyl protecting group on 6-O). However, no additional data was presented to confirm the stereochemistry at 8-C and 9-C.

While characterising spiroketal 2 we noticed that, though stable in DMSO- $d_{6}$, it degrades in $\mathrm{CDCl}_{3}$ (results not shown). Unstabilised $\mathrm{CDCl}_{3}$ slowly decomposes to produce acidic byproducts, ultimately producing traces of hydrochloric acid which we assumed was the cause of further transformations of spiroketal 2. Since the erythromycin A acid degradation ends the with formation of the spiroketal, we were interested to characterise these unexpected products derived from spiroketal 2. Erythronolides as polyhydroxyketones could undergo skeletal transformations such as epimerisations, spiroketalisation, translactonisation, dehydroxylations, etc. [57]. Grover et al. [58] have previously shown that during the oximation of erythromycin A, unexpected side reactions led to the formation of a 6,9-intramolecular enol ether, translactonisation or formation of anhydroerythromycin A, perhaps resulting from acetic acid traces generated during the reaction acting upon either the starting material, or deoximation of the intended product. We therefore repeated the experiment in fresh, stabilised chloroform to study the reaction kinetics and to isolate and fully characterise the products.

\section{Structure elucidation of compound 2}

Analysis of HMBC spectra, as well as chemical shift comparison with the parent compound 1 [39], showed that the 9-Csignal of 2 exhibits a large upfield shift to $107.1 \mathrm{ppm}$ (168.1 ppm in 1), as well as intense HMBC cross-peaks with 4- $\mathrm{H}$ and 5- $\mathrm{H}$. At the same time, the carbon signal of $12-\mathrm{C}$ in $\mathbf{2}$ is found at $81.8 \mathrm{ppm}$ (73.4 ppm in 1). These suggest their participation in a [4.5]spiroketal ring system. Such types of spiroketals usually appear in two conformations - typically in a more stable anomeric and most often in a less stable nonanomeric form [23]. To determine the configuration at 9-C and elucidate the conformation of 2, nOe analysis was performed (Tables SI1 and SI2, in Supporting Information File 1), followed by molecular modelling. Very strong nOe correlations between 2-H, 5-H and $10-\mathrm{H}$ observed in both DMSO- $d_{6}$ and $\mathrm{CDCl}_{3}$ attest to their close spatial proximity (2.0-2.6 $\AA$ ). Other characteristic observed nOe interactions are: very strong $4-\mathrm{H} \leftrightarrow 6-\mathrm{Me}$, $8-\mathrm{Me} \leftrightarrow 10-\mathrm{Me}, 3-\mathrm{H} \leftrightarrow 4-\mathrm{Me}, 5-\mathrm{H} \leftrightarrow 7-\mathrm{Hax}, 5-\mathrm{H} \leftrightarrow 6-\mathrm{Me}$, 5 -H $\leftrightarrow 10$-Me correlations and a weak interaction between $4-\mathrm{Me}$ and $5-\mathrm{H}$.

To simplify the generation of the three-dimensional structure and avoid time-consuming molecular dynamic simulations, the starting model of $\mathbf{2}$ was created from the X-ray single crystal structure of tricyclic spiroketal (CSD entry: ERYTHR) [55], with replacement of the 6-hydroxy group by 6-methoxy. A twostep minimization process consisted of adding energy constraints to the X-ray structure followed by unconstrained minimization. Significant conformational changes were not expected due to the rigidity of the tricyclic system. A low energy conformation of $\mathbf{2}$ is presented in Figure 1.

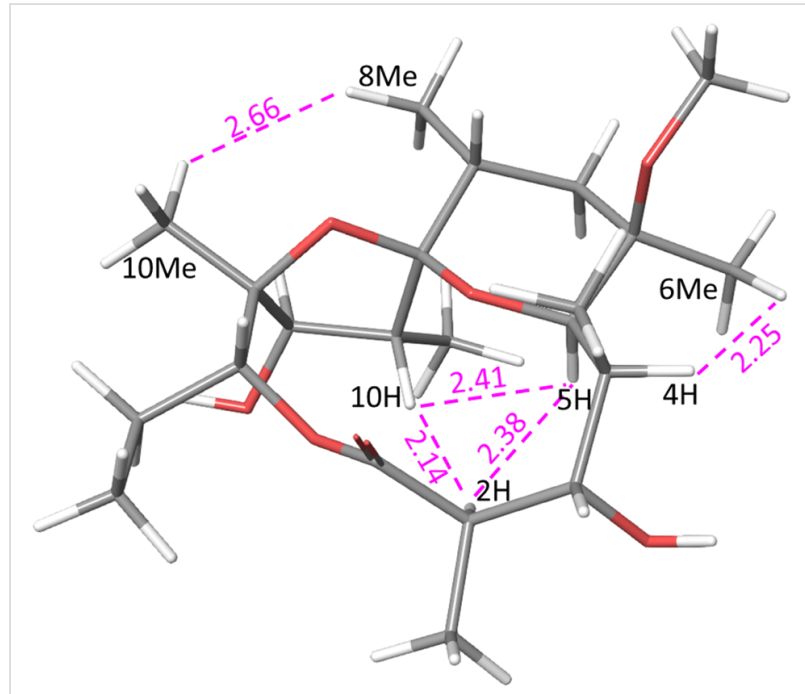

Figure 1: Modelling-derived structure of 2 showing key nOe interactions (calculated distances in $\AA$ ).

Analogous to pyranoside conformations, the highly substituted tetrahydropyran ring is in a ${ }^{5} C_{8}$ conformation [59] and it is not anomerically stabilised. The bulky 6-OMe group and 10-C are axially oriented while 4-C, 6-Me, 8-Me and 12-O are equatorial. Experimental evidences for such ${ }^{5} C_{8}$ conformation is the large ${ }^{3} J_{7-\mathrm{H}, 8-\mathrm{H}}$ coupling constant $(14 \mathrm{~Hz})$ suggesting equatorial orientation of 8-Me. The strong 1,3-axial interactions between 5-H and axial $7-\mathrm{H}$ confirms their proximity and equatorial orientation of 4-C. Strong correlation between 6-OMe and equatorial 7-H with absence of interactions with axial 7- $\mathrm{H}$ suggests that 6-OMe is axially oriented. The alternative ${ }^{8} C_{5}$ conformation would be unfavourable due to adverse 1,3-diaxial interactions between the four substituents.

Having determined the stereochemistry at position 9-C to be $R$, we compared the chemical shifts of 2 to the 6-OTES protected spiroketal reported by Carreira [56]. The close correspondence of the chemical shifts between the two suggests that both compounds share the same configuration.

\section{Reaction kinetics}

Dissolution in fresh stabilised $\mathrm{CDCl}_{3}$ showed no evidence of change, suggesting that observed transformations were caused 
by acidic species arising from chloroform decomposition. It was shown $[16,23,60]$ that acidic media can catalyse polyhydroxy ketone transformations to spiroketals. Therefore, we undertook the study of the acid-promoted transformation of $\mathbf{2}$ by accumulation of time-dependent ${ }^{1} \mathrm{H}$ NMR spectra at constant temperature (Figure 2).

The mole fractions of the species in the mixture were calculated from the collected spectra using the $13-\mathrm{H}$ integrals and used to examine the kinetics (Figure 3), as well as gain insight into the reaction mechanism. The model of consecutive firstorder reactions with a reversible second step [61]:

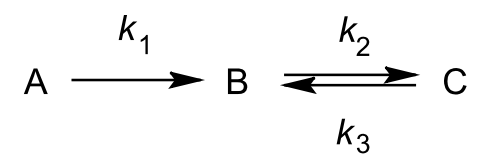

was used to describe the observed time-dependencies of each species in the mixture, giving calculated rate constants $k_{1}$ of $1.15 \times 10^{-6} \mathrm{~s}^{-1}$ for the first reaction step, with $k_{2}$ and $k_{3}$ of $3.63 \times 10^{-7} \mathrm{~s}^{-1}$ and $5.28 \times 10^{-8} \mathrm{~s}^{-1}$, respectively, for the second (equilibrium) reaction $\left(R^{2}=0.9978113\right)$.

Conversion of $\mathbf{2}$ into compounds $\mathbf{3}$ and $\mathbf{4}$ proceeds to completion after approximately 47 days $\left([2] /[2]_{0}=1 \%\right.$ at $\left.1123 \mathrm{~h}\right)$. The concentration of compound 3 first increases reaching the maximum after 18 days and then decreases, while the concentration of compound 4 steadily increases throughout the experiment. The reaction ends in an apparent equilibrium with relative concentrations of $13 \%$ and $87 \%$, for 3 and 4 , respectively. These findings indicate that $\mathbf{3}$ is the kinetic and $\mathbf{4}$ the thermody-

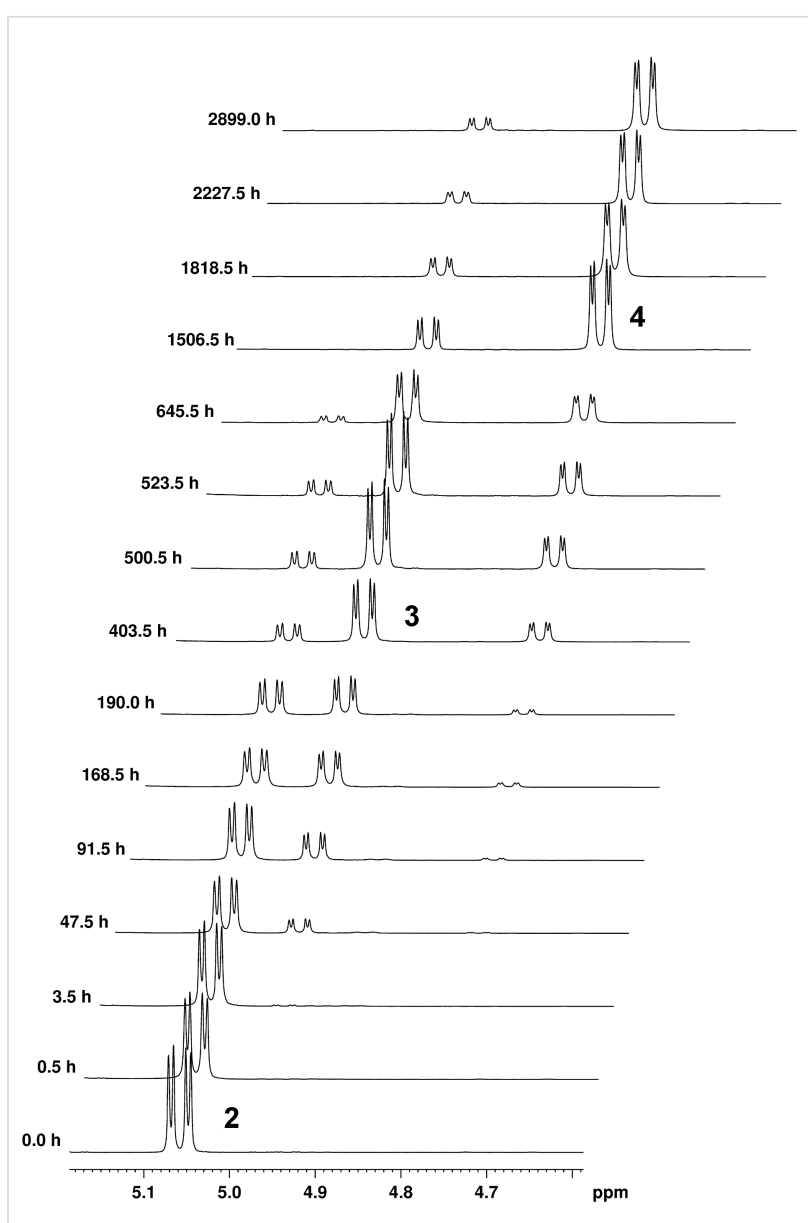

Figure 2: Time-dependent ${ }^{1} \mathrm{H}$ NMR spectra of 2, 3 and $\mathbf{4}$ (13-H multiplets region). The experiments were performed on $0.1 \mathrm{M}$ chloroform- $d_{1}$ solution of 2 at $25^{\circ} \mathrm{C}$. Spectra were recorded at appropriate time intervals after the initial addition of $10 \mu \mathrm{L}$ of $1 \mathrm{M} \mathrm{HCl}$.

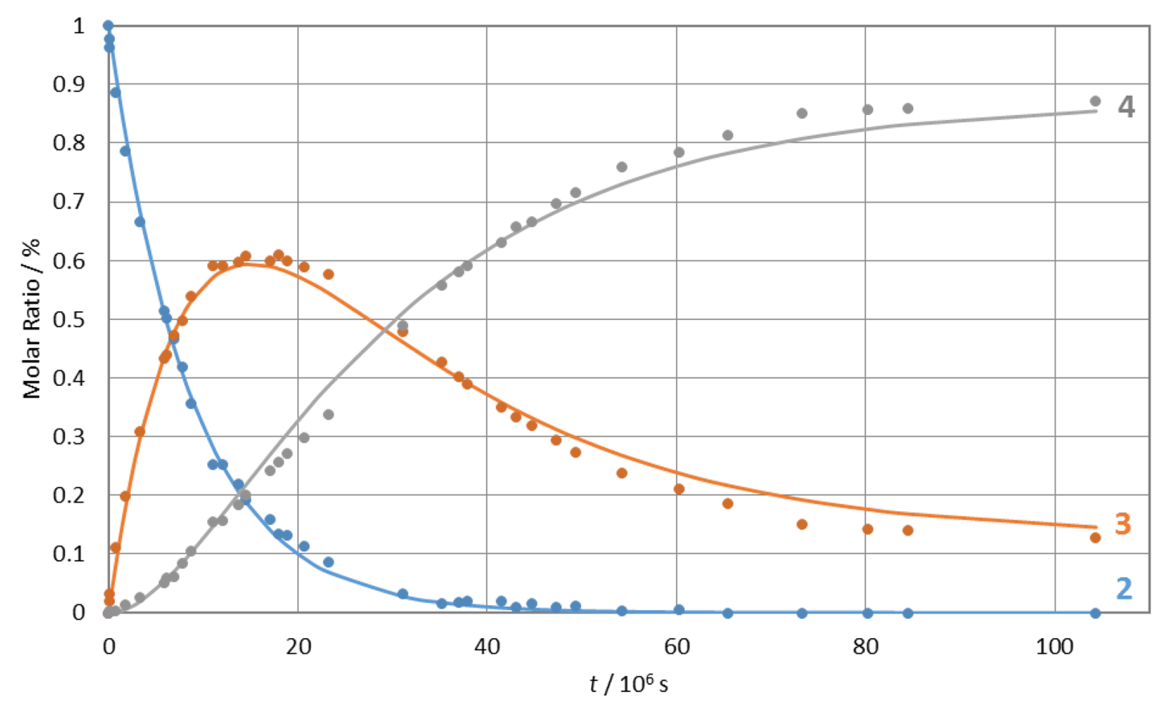

Figure 3: Interconversion kinetics of compounds $\mathbf{2}$ (blue), $\mathbf{3}$ (orange) and $\mathbf{4}$ (grey). 
namic product. In an effort to effect full conversion of $\mathbf{3}$ to $\mathbf{4}$, after 120 days the mixture was heated in a microwave reactor for 30 minutes at $120^{\circ} \mathrm{C}$. However, the product ratio was found to be unchanged.

\section{Structure elucidation of compound $\mathbf{3}$}

The main feature of compound $\mathbf{3}$ is the appearance of a double bond between 10-C and 11-C, as evidenced by the signal in the ${ }^{1} \mathrm{H}$ NMR spectrum at $5.65 \mathrm{ppm}$ and relevant $\mathrm{HMBC}$ correlations. The initial 3D structure of the compound was generated from the previously modelled conformation of $\mathbf{2}$ by eliminating $10-\mathrm{H}$ and 11-OH, forming an endocyclic double bond. Minimization of this structure resulted, as expected, in small changes at positions 10-C and 11-C (Figure 4), while all other atoms remained in almost identical positions. The tetrahydropyran ring in 3 also assumes ${ }^{5} C_{8}$ conformation which explains the observed system of nOe correlations between $2-\mathrm{H}, 5-\mathrm{H}$ and $10-\mathrm{Me}(2.2-2.9 \AA)$, as well as $8-\mathrm{Me} \leftrightarrow 10-\mathrm{Me}(2.7 \AA)$ and $11-\mathrm{H} \leftrightarrow 14_{\mathrm{b}}-\mathrm{H}(2.8 \AA)$ interactions, all shown in Table SI3, in Supporting Information File 1. The coupling constants ${ }^{3} J_{8-\mathrm{H}, 7-\mathrm{Ha}}$ and ${ }^{3} J_{8-\mathrm{H}, 7-\mathrm{Hb}}$ (one strong, antiperiplanar and one weak, synclinal) suggest an axial orientation of 8-H and equatorial position of 8 -Me. Similar to 2 , the six-membered tetrahydropyran assumes an anomerically non-stabilised chair conformation with the larger 6-methoxy substituent in the axial position.

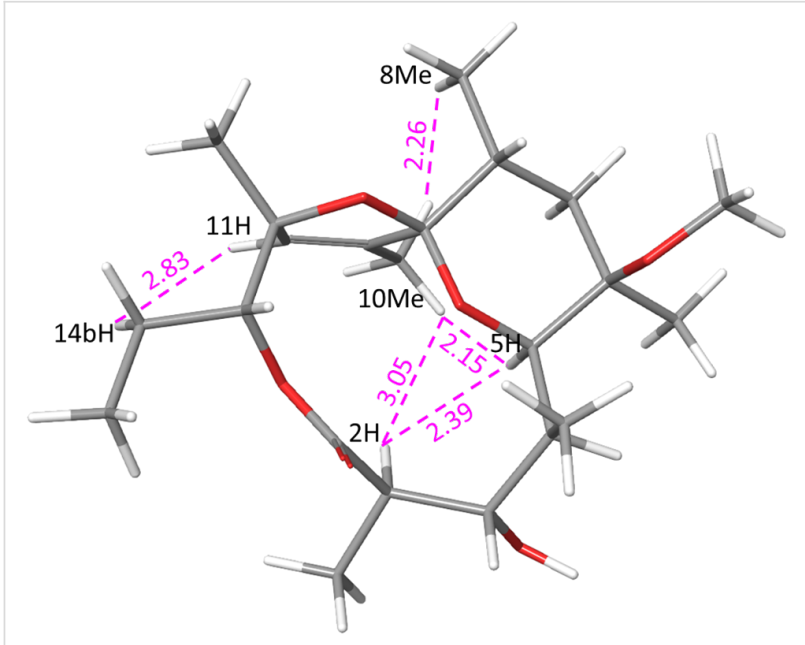

Figure 4: Modelling-derived structure of $\mathbf{3}$ showing key nOe interactions (calculated distances in $\AA$ ).

\section{Structure elucidation of compound $\mathbf{4}$}

Determining the structure of the thermodynamically stable product 4 proved to be more challenging. Our initial hypothesis was that it was an anomerically stabilised ${ }^{8} C_{5}$ conformer of $\mathbf{3}$ with the 6-methoxy group in the more stable equatorial position. Molecular mechanics calculations, however, showed that such a structure should be energetically unfavourable due to 1,3-repulsion between the axial 6-methyl and 8-methyl groups. Therefore, nOe interactions (Table SI4, Supporting Information File 1) and proton-proton coupling constants (Table SI5, Supporting Information File 1) were introduced into the modelling calculations as distance and angle constraints.

Various conformations of the proposed structure were analysed by molecular mechanics calculations, but only one structure (Figure 5), with inverted stereochemistry at the 8-C position $(8 S)$ was consistent with all measured nOe contacts and vicinal coupling constants.

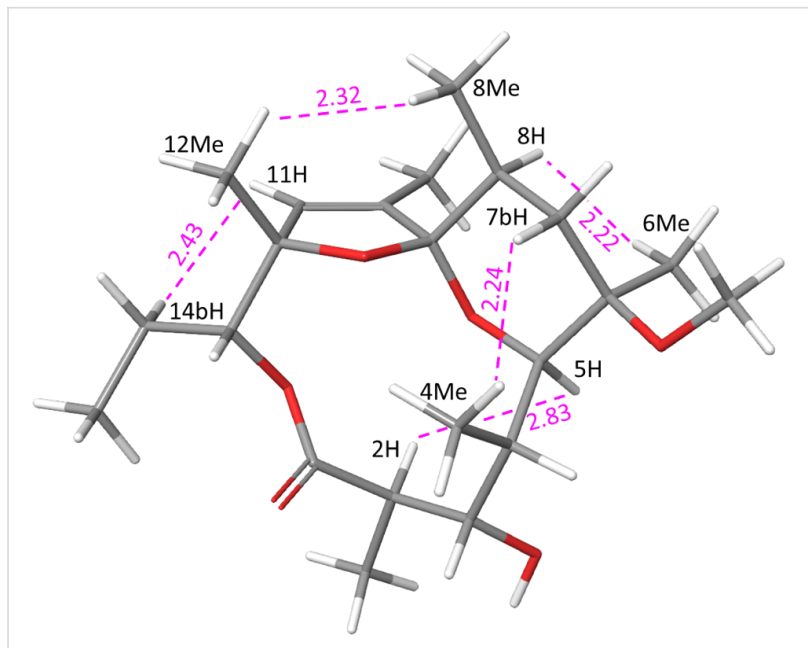

Figure 5: Modelling-derived structure of compound $\mathbf{4}$ showing key nOe interactions (calculated distances in $\AA$ ).

Numerous nOe interactions support the proposed structure. Correlations of 5-H with both substituents at position 6 suggest that this hydrogen atom is in equatorial position, placing 4-C axially. For comparison, only the strong interaction $5-\mathrm{H} \leftrightarrow 6-\mathrm{Me}$ is observed in both $\mathbf{2}$ and 3. Furthermore, the absence of nOe correlation between 5-H and either of the 7-Hs (contrary to both 2 and 3) confirms its equatorial position. Strong interactions of 8 -H with both 6 -Me and $10-\mathrm{Me}$, as well as large ${ }^{3} J_{7-\mathrm{H}, 8-\mathrm{H}}$ suggest equatorial orientation for 8 -Me.

\section{Structural comparisons}

The most significant structural changes between $\mathbf{3}$ and $\mathbf{4}$ are a consequence of the configurational change within the tetrahydropyran ring (Figure 6).

Compound 4 is approximately $0.9 \mathrm{kcal} \mathrm{mol}^{-1}$ more stable than 3 (calculated in $\mathrm{CHCl}_{3}$ using the MMFF94 force field). Obviously, the anomeric effect has a strong influence on the preferred conformation of the spiroketal ring. In 4 the tetrahydropyran ring adopts the ${ }^{8} C_{5}$-conformation with the 


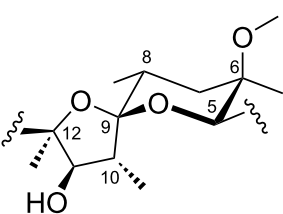

2

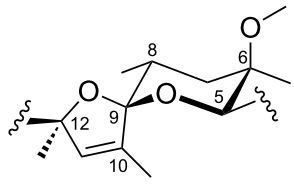

3

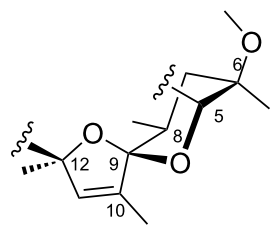

4

Figure 6: Comparison of the spiroketal ring system stereochemistry and conformations in compounds 2-4.

6-methoxy group in the equatorial and the three substituents in the axial positions (12-O bridge, 4-C and 6-Me). Inversion of the 8 -C configuration results in 8 -Me adopting the equatorial position, removing unfavourable steric interactions (Figure 7).

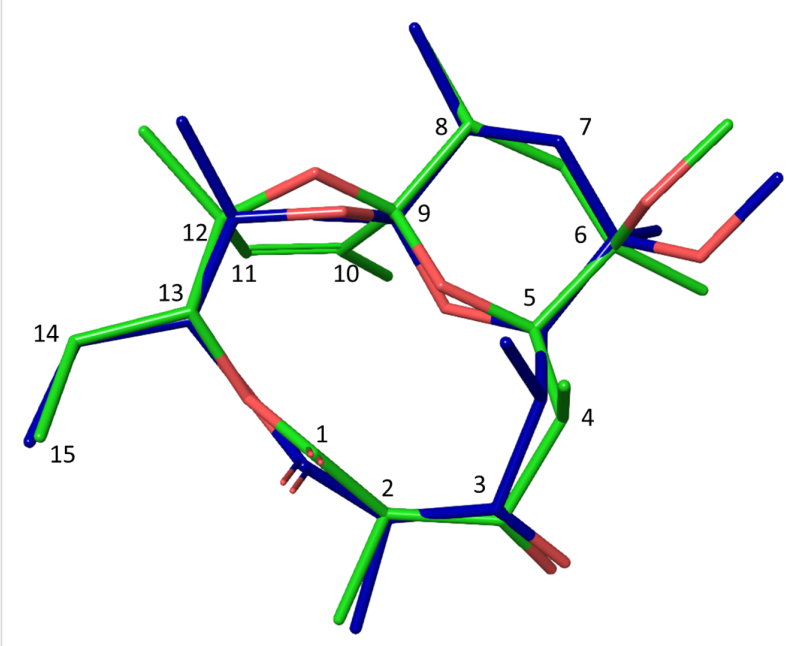

Figure 7: Overlay of the computed structures of $\mathbf{3}$ (green) and $\mathbf{4}$ (blue)

\section{Reaction mechanism}

Although uncommon, epimerisation at position 8-C was reported earlier [62] in structurally similar compounds when exposed to analogous reaction conditions. A plausible mechanism of the transformations as discussed is presented in Scheme 2.

The whole equilibrium process most likely consists of a series of hemiketal and enol ether transformations. Thus the elusive intermediate $\mathbf{A}$ in acidic media forms a hemiketal $\mathbf{B}$ (B1 or B2). From our data and literature precedents it is not clear if the 6-membered (B1) or the 5-membered (B2) intermediate is formed first. Based on chemical calculations Hassanzadeh et al. suggested 12-O-enol ether formation (type C2) and final spiroketalisation [42] via the corresponding oxocarbenium type transition state. Carreira et al. on the other hand isolated a 6-membered enol ether (type C1) and further transformed it into a [4.5]spiroketal [56]. Whichever pathway is applicable, it transpires through loss and regain of chirality either at 8-C (C1) or 10-C (C2) and final formation of the spiroketal 2. Loss and regain of chirality at 8 -C proceeds with complete retention of the configuration with the methyl group in an equatorial position on the tetrahydropyran ring. Prolonged acidic treatment of $\mathbf{2}$ leads either back to $\mathbf{C 1}$ or to its isomer $\mathbf{C 2}$. The latter loses a molecule of water via an intramolecular $\mathrm{S}_{\mathrm{N}} 2$ ' mechanism forming the unsaturated spiroketal 3. Repeated spiroketal opening leads to the conjugated enol ether $\mathbf{E}$ with loss of the chiral centre at 8-C. Reports on clarithromycin acid degradation suggest that enol ethers of this type exist as mixtures of $8 E, 10 Z$ and $8 Z, 10 Z$ isomers [49], that might even equilibrate [50]. It is not clear which step is C-8 stereo determining but we might assume that spiroketalisation of each of $E$ isomers goes through an oxocarbenium type transition state that have different stereochemistry on C-8. That reflects in formation of the two isomeric products $\mathbf{3}$ and $\mathbf{4}$, with the latter anomerically stabilized and thermodynamically more stable. In this case the complete epimerization to $8 S$ occurs with the methyl group again occupying an equatorial position.

A structurally similar acid-catalyzed erythromycin A decomposition product, erythralosamine [40,41] containing a [4.4] rather than [4.5]spiroketal ring and double bond between 10-C and 11-C has been characterised by X-ray analysis [63]. Only one enantiomer at 8-C was isolated, showing retention of stereochemistry. This would support the hypothesis that the difference in energies of the 6-membered ring anomers relative to a 5 -membered ring is sufficient to drive the conversion of $\mathbf{3}$ to $\mathbf{4}$.

\section{Conclusion}

In this paper we have presented the acid-promoted modification of 6-O-methyl-9 $(E)$-hydroxyiminoerythronolide A into three rigid tricyclic spiroketal systems $\mathbf{2 , 3}$ and $\mathbf{4}$. Compound $\mathbf{2}$ proved to be stable in non-acidic media. After acidic treatment two new dehydrated molecules are formed: compound $\mathbf{3}$ which with time spontaneously transforms into the thermodynamically more stable 4 . The most significant structural change is inversion of configuration at 8-C accompanied by a con- 


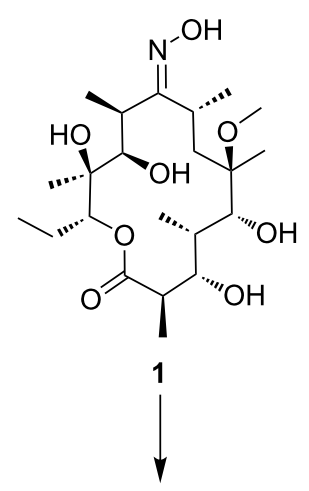

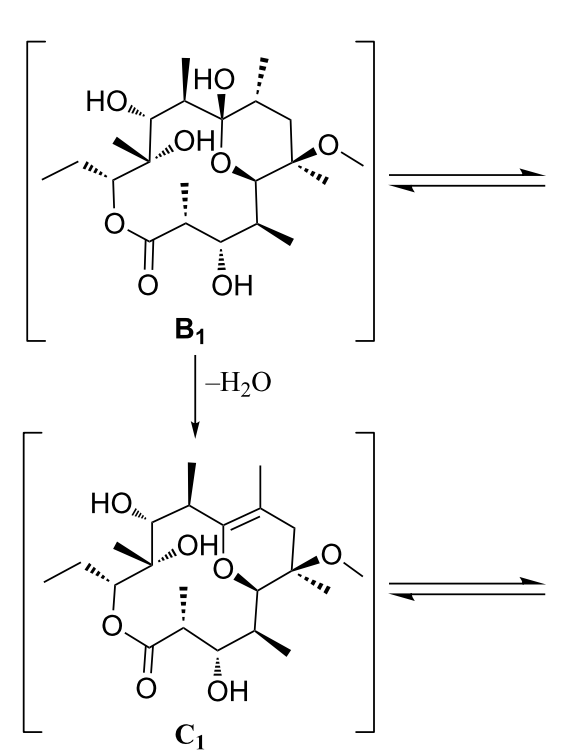<smiles>CC[C@H](OC(=O)C(C)C)[C@@](C)(O)C(O)C(C)C(=O)C(C)C(C)C</smiles>

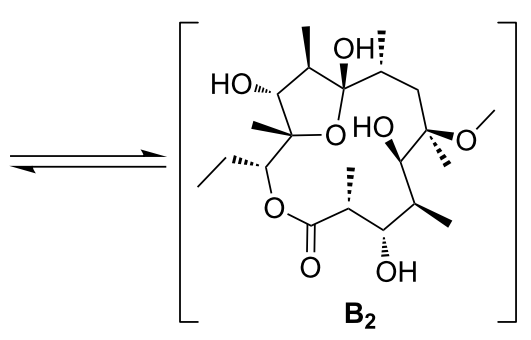

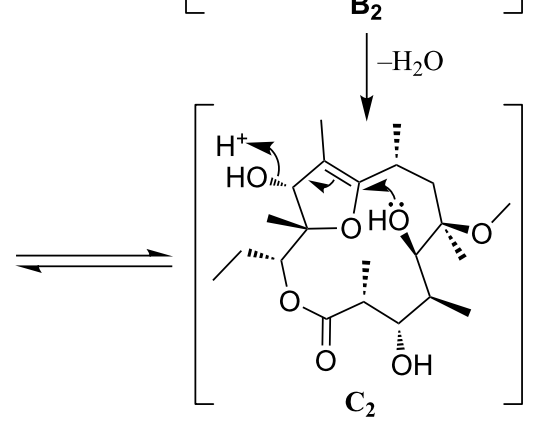

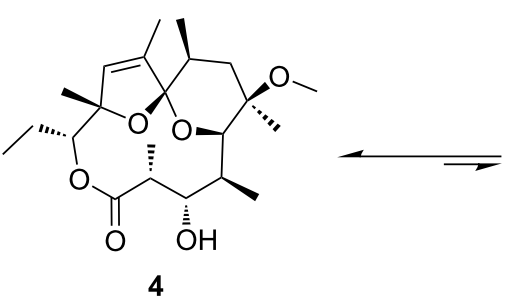

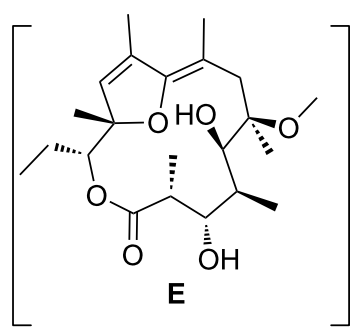

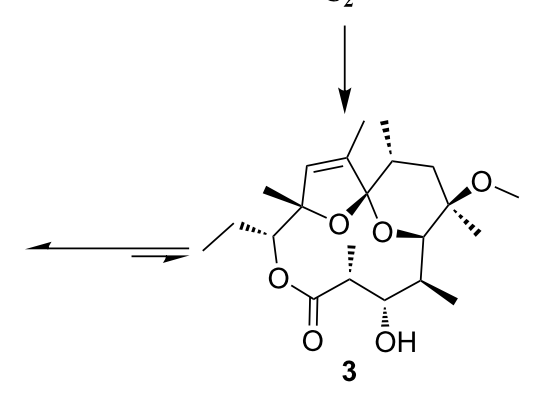

Scheme 2: Postulated mechanism for the formation of compounds 2-4.

formational change of the tetrahydropyran ring from one chair conformation ${ }^{5} C_{8}$ into another, anomerically stabilised, ${ }^{8} C_{5}$ conformation. These transformations give a facile route for the synthesis of novel macrolide spiroketals.

\section{Experimental \\ Materials}

Oxime 1 was synthesized according to the previously published procedure $[39,51,64]$. The structures of all compounds were confirmed by NMR spectroscopy, LC-HRMS and molecular modelling. Both NMR spectroscopy and LC-MS were used to ascertain purity (greater than $95 \%$ for all compounds).

\section{Reaction kinetics}

$30 \mathrm{mg}$ of 2 was dissolved in $0.7 \mathrm{~mL}$ chloroform- $d_{1}$ giving the final compound concentration of $0.1 \mathrm{M}$. Comparison of the proton spectrum taken immediately after dilution and the proton spectrum taken after 3 days showed no differences at all. Moments prior to the beginning of the kinetics experiment $10 \mu \mathrm{L}$ of $1 \mathrm{M} \mathrm{HCl}$ was added into the NMR tube. Immediately the reaction started and was monitored by ${ }^{1} \mathrm{H}$ NMR spec- 
troscopy at $25{ }^{\circ} \mathrm{C}$. The rate constants were calculated using Microsoft Excel 2013 (32 bit) for Microsoft Windows 8.1 (64 bit) with Solver add-in (see Supporting Information File 1).

\section{NMR Spectroscopy}

One and two-dimensional NMR spectra $\left({ }^{1} \mathrm{H}, \mathrm{APT}, \mathrm{COSY}\right.$, NOESY, ROESY, edited-HSQC and HMBC) were recorded on Bruker Avance III 600 and Bruker Avance DRX 500 spectrometers, both equipped with $5 \mathrm{~mm}$ diameter inverse detection probe with z-gradient accessory, as well as a Bruker Avance DPX 300 spectrometer using a $5 \mathrm{~mm}$ DUL ${ }^{1} \mathrm{H} /{ }^{13} \mathrm{C}$ probe. All spectra were recorded using standard Bruker pulse sequences on compounds dissolved in DMSO- $d_{6}$ and $\mathrm{CDCl}_{3}$ at $25{ }^{\circ} \mathrm{C}$, with TMS as the internal standard. NOESY spectra were obtained with a $400 \mathrm{~ms}$ mixing time. NMR analysis of compound 2 was performed in both DMSO- $d_{6}$ and $\mathrm{CDCl}_{3}$. Initial full assignment and conformational analysis of compound $\mathbf{3}$ was performed at the point of maximum concentration of compound 3 . The final kinetics reaction mixture was evaporated to dryness and re-dissolved in DMSO- $d_{6}$ for the structure elucidation of $\mathbf{4}$, as signal broadening occurred in the NMR spectra recorded in $\mathrm{CDCl}_{3}$. The compounds 3 and $\mathbf{4}$ were later re-synthesised, isolated by preparative HPLC-MS and fully assigned as individual compounds.

\section{Molecular modelling}

The model of 2 was generated from the single crystal X-ray structure of erythronolide A anhydro derivative (CSDC refcode: ERYTHR [55]) and minimized with constraints of $1000 \mathrm{kcal}$ on all atoms with known X-ray coordinates. The model of $\mathbf{3}$ was generated from the model of compound 2 . The model of $\mathbf{4}$ was obtained by molecular modelling with NMR constraints: strong nOe correlations were converted to a distance constraint of 2.0-2.5 $\AA$, medium as 2.5-3.5 $\AA$ and weak as 3.5-5.0 $\AA$, while vicinal coupling constants were converted to angle constraints. All calculations were performed using the MMFF94 force field implemented in Schrodinger Maestro 2015-1 [65].

\section{Preparative LC-MS}

Compounds were purified using a Waters Mass Directed AutoPurification System using a XBridge MS C18 column $(19 \times 100 \mathrm{~mm}, 5 \mu \mathrm{m})$ and isocratic technique (using mixture of eluents $40 \% 10 \mathrm{mM} \mathrm{NH}_{4} \mathrm{HCO}_{3} / \mathrm{pH} 10$ and $\left.60 \% \mathrm{CH}_{3} \mathrm{CN}\right)$. The flow rate was maintained at $17 \mathrm{~mL} / \mathrm{min}$.

\section{LC-HRMS}

Positive ion mass spectra were acquired on a Micromass Q-Tof2 equipped with a Z-spray interface, operated in positive ion mode over a mass range of $100-1000 \mathrm{Da}$, with a scan time of $1.0 \mathrm{~s}$ and an interscan delay of $0.1 \mathrm{~s}$. Reserpine was used as the external calibrant lock mass $\left([\mathrm{M}+\mathrm{H}]^{+}=609.2812 \mathrm{Da}\right)$. Ioniza- tion was achieved with a spray voltage of $3.5 \mathrm{kV}$, a cone voltage of $20 \mathrm{~V}$, with cone and desolvation gas flows of 20-30 and $500 \mathrm{~L} / \mathrm{h}$, respectively. The source block and desolvation temperatures were maintained at $125^{\circ} \mathrm{C}$ and $150{ }^{\circ} \mathrm{C}$, respectively. The elemental composition was calculated using MassLynx v4.1 for the $[\mathrm{M}+\mathrm{H}]^{+}$(or other mentioned adducts) and the mass error quoted as ppm. Chromatography was performed using an Agilent 1100 HPLC instrument equipped with a XBridge $2.1 \times 150 \mathrm{~mm} 3.5 \mu \mathrm{m}$ column (Waters, Milford, USA). Gradient elution was carried out with the mobile phases as (A) $10 \mathrm{mM} \mathrm{NH}_{4} \mathrm{HCO}_{3}$, pH 10 and (B) $\mathrm{CH}_{3} \mathrm{CN}$.

\section{Synthesis}

\section{Preparation of compound 2}

6-O-Methyl-9(E)-hydroxyiminoerythronolide A (1) $(0.6 \mathrm{~g}$, $1.341 \mathrm{mmol})$ was dissolved in EtOH $(20 \mathrm{~mL})$. Water was added (24 mL), followed by $\mathrm{HCOOH}(142.2 \mu \mathrm{L}, 3.75 \mathrm{mmol})$ and $\mathrm{Na}_{2} \mathrm{~S}_{2} \mathrm{O}_{5}(1.02 \mathrm{~g}, 5.37 \mathrm{mmol})$ with continuous stirring at room temperature. The reaction mixture was heated to about $70{ }^{\circ} \mathrm{C}$ and after 45 minutes the additional amount of $\mathrm{Na}_{2} \mathrm{~S}_{2} \mathrm{O}_{5}(1.02 \mathrm{~g}$, $6.38 \mathrm{mmol}$ ) was added. After 4 hours the heating was turned off and the reaction mixture was left to stir overnight at room temperature. The reaction mixture was concentrated and extracted with DCM $(6 \times 20 \mathrm{~mL})$. Combined organics were washed with sat. aq. $\mathrm{NaHCO}_{3}(3 \times 10 \mathrm{~mL})$, brine $(2 \times 10 \mathrm{~mL})$ and dried over $\mathrm{Na}_{2} \mathrm{SO}_{4}$. Evaporation of solvent afforded crude product 2 which was further purified by column chromatography on silica-gel (LC-Packing $60 \mathrm{~mL}, 20 \mathrm{~g}$, Supelco) eluting with $100 \rightarrow 95 \% \mathrm{CH}_{2} \mathrm{Cl}_{2} /\left(\mathrm{MeOH} / \mathrm{NH}_{4} \mathrm{OH} 9: 1.5\right)$. The product was obtained as white powder. $0.197 \mathrm{~g}(33.9 \%)$.

${ }^{1} \mathrm{H}$ NMR (600 MHz, DMSO-d $\left.d_{6}\right) \delta 0.71(\mathrm{t}, J=7.4 \mathrm{~Hz}, 3 \mathrm{H}$, $15-\mathrm{H}), 0.89$ (d, $J=7.5 \mathrm{~Hz}, 3 \mathrm{H}, 8-\mathrm{Me}), 0.98$ (s, 3H, 6-Me), 1.04 $(\mathrm{d}, J=7.5 \mathrm{~Hz}, 3 \mathrm{H}, 4-\mathrm{Me}), 1.16(\mathrm{~s}, 3 \mathrm{H}, 12-\mathrm{Me}), 1.23$ (d, $J=7.0 \mathrm{~Hz}, 3 \mathrm{H}, 2-\mathrm{Me}), 1.27$ (d, $J=7.3 \mathrm{~Hz}, 3 \mathrm{H}, 10-\mathrm{Me})$, 1.48-1.54 (m, 1H, 14-H), 1.54-1.60 (dd, $J=14.0 \mathrm{~Hz}, 1 \mathrm{H}, 7-\mathrm{H})$, $1.76-1.84(\mathrm{~m}, 1 \mathrm{H}, 8-\mathrm{H}), 1.88$ (dd, $J=14.8,3.5 \mathrm{~Hz}, 1 \mathrm{H}, 7-\mathrm{H})$, 1.93-1.99 (m, 1H, 14-H), 1.97-2.02 (m, 1H, 4-H), 2.34 (dq, $J=9.2,6.9 \mathrm{~Hz}, 1 \mathrm{H}, 2-\mathrm{H}), 2.97-3.05(\mathrm{~m}, 1 \mathrm{H}, 10-\mathrm{H}), 3.01$ (s, 3H, 6-OMe), 3.27 (ddd, $J=9.2,5.4,1.3 \mathrm{~Hz}, 1 \mathrm{H}, 3-\mathrm{H}), 3.36$ (dd, $J=$ 10.6, $6.0 \mathrm{~Hz}, 1 \mathrm{H}, 11-\mathrm{H}), 3.52$ (s, $1 \mathrm{H}, 5-\mathrm{H}), 4.63$ (dd, $J=12.0$, $3.1 \mathrm{~Hz}, 1 \mathrm{H}, 13-\mathrm{H}), 4.77(\mathrm{~d}, J=5.4 \mathrm{~Hz}, 1 \mathrm{H}, 3-\mathrm{OH}), 5.26$ (d, $J=$ $6.1 \mathrm{~Hz}, 1 \mathrm{H}, 11-\mathrm{OH}) ;{ }^{13} \mathrm{C}$ NMR $\left(150 \mathrm{MHz}, \mathrm{DMSO}-d_{6}\right) \delta 10.6$ (15-C), 14.8 (8-Me), 15.1 (4-Me), 15.4 (10-Me), 18.5 (2-Me), 20.5 (6-Me), 23.7 (12-Me), 23.8 (14-C), 34.1 (8-C), 34.8 (7-C), 41.5 (4-C), 44.9 (2-C), 47.0 (10-C), 47.9 (6-OMe), 74.4 (6-C), 76.0 (5-C), 77.9 (3-C), 80.1 (13-C), 81.8 (12-C), 85.8 (11-C), 107.1 (9-C), $173.3(1-\mathrm{C}) ;{ }^{1} \mathrm{H}$ NMR $\left(500 \mathrm{MHz}, \mathrm{CDCl}_{3}\right) \delta 0.86$ (t, $J=7.3 \mathrm{~Hz}, 3 \mathrm{H}, 15-\mathrm{H}), 0.98(\mathrm{~d}, J=7.3 \mathrm{~Hz}, 3 \mathrm{H}, 8-\mathrm{Me}), 1.07$ (s, 3H, 6-Me), 1.26 (d, $J=7.5 \mathrm{~Hz}, 3 \mathrm{H}, 4-\mathrm{Me}), 1.31$ (s, 3H, 12-Me), 1.40 (d, $J=6.7 \mathrm{~Hz}, 3 \mathrm{H}, 2-\mathrm{Me}), 1.41$ (d, $J=7.3 \mathrm{~Hz}, 3 \mathrm{H}$, 
$10-\mathrm{Me}), 1.60(\mathrm{dd}, J=14.8,13.9 \mathrm{~Hz}, 1 \mathrm{H}, 7-\mathrm{H}), 1.74(\mathrm{dqd}$, $J=14.0,7.4,3.5 \mathrm{~Hz}, 1 \mathrm{H}, 14-\mathrm{H}), 1.86(\mathrm{dqd}, J=14.6,11.9$, $7.3 \mathrm{~Hz}, 1 \mathrm{H}, 14-\mathrm{H}), 1.85$ (br. s., $1 \mathrm{H}, 3-\mathrm{OH}), 1.95$ (dd, $J=14.9$, $3.6 \mathrm{~Hz}, 1 \mathrm{H}, 7-\mathrm{H}), 1.99$ (d, $J=11.8 \mathrm{~Hz}, 1 \mathrm{H}, 11-\mathrm{OH}), 2.08$ (q, $J=$ $7.6 \mathrm{~Hz}, 1 \mathrm{H}, 4-\mathrm{H}), 2.12$ (dqd, $J=10.1,7.1,3.5 \mathrm{~Hz}, 1 \mathrm{H}, 8-\mathrm{H})$, $2.46(\mathrm{dq}, J=9.2,6.9 \mathrm{~Hz}, 1 \mathrm{H}, 2-\mathrm{H}), 2.87(\mathrm{dq}, J=9.8,7.5 \mathrm{~Hz}$, $1 \mathrm{H}, 10-\mathrm{H}), 3.09$ (s, 3H, 6-OMe), 3.52 (dd, $J=11.5,9.8 \mathrm{~Hz}, 1 \mathrm{H}$, 11-H), 3.54 (s, 1H, 5-H), 3.69 (dd, $J=9.5,1.5 \mathrm{~Hz}, 1 \mathrm{H}, 3-\mathrm{H})$, $5.06(\mathrm{dd}, J=12.1,3.5 \mathrm{~Hz}, 1 \mathrm{H}, 13-\mathrm{H}) ;{ }^{13} \mathrm{C} \mathrm{NMR}(126 \mathrm{MHz}$, $\left.\mathrm{CDCl}_{3}\right) \delta 10.5$ (15-C), 15.0 (4-Me), 15.1 (8-Me), 16.1 (10-Me), 18.4 (2-Me), 20.9 (6-Me), 23.9 (12-Me), 25.0 (14-C), 34.2 (8-C), 35.6 (7-C), 42.6 (4-C), 45.3 (2-C), 48.2 (6-OMe), 50.5 (10-C), 74.4 (6-C), 77.2 (5-C), 79.3 (3-C), 82.1 (13-C), 83.0 (12-C), 89.1 (11-C), 107.9 (9-C), 173.0 (1-C) ppm; HRMS: $[\mathrm{M}+\mathrm{H}]^{+}$measured 415.2679, calculated 415.2696, error $-4.1 \mathrm{ppm}$

\section{Preparation of compounds $\mathbf{3}$ and $\mathbf{4}$}

Two drops of $38 \% \mathrm{DCl}$ solution in $\mathrm{D}_{2} \mathrm{O}$ were added to the solution of compound $2(82.6 \mathrm{mg})$ in $\mathrm{CDCl}_{3}(5.5 \mathrm{~mL})$. The reaction mixture was left to stir and its progress was monitored with ${ }^{1} \mathrm{H}$ NMR, until the starting compound disappeared and the $\mathbf{3}$ to 4 ratio was approximately 50:50. The reaction mixture was then evaporated and purified by preparative LC-MS (Instrument: Waters purification system - ZQ) to give compounds 3 (16 mg, purity: $98.7 \%$ ) and 4 (37 mg, purity: $98.5 \%$ ) as white solids.

Compound 3: ${ }^{1} \mathrm{H}$ NMR $\left(600 \mathrm{MHz}, \mathrm{CDCl}_{3}\right) \delta 0.85(\mathrm{~d}$, $J=7.3 \mathrm{~Hz}, 3 \mathrm{H}, 8-\mathrm{Me}$ ), 0.87 ( t, $J=7.3 \mathrm{~Hz}, 3 \mathrm{H}, 15-\mathrm{H}), 1.10$ (s, $3 \mathrm{H}, 6-\mathrm{Me}$ ), 1.23 (d, $J=7.5 \mathrm{~Hz}, 3 \mathrm{H}, 4-\mathrm{Me}), 1.27$ (s, 3H, 12-Me), $1.32(\mathrm{~d}, J=7.2 \mathrm{~Hz}, 3 \mathrm{H}, 2-\mathrm{Me}), 1.35$ (ddq, $J=14.0,11.9$, $7.3 \mathrm{~Hz}, 1 \mathrm{H}, 14-\mathrm{H}), 1.46$ (dd, $J=14.1 \mathrm{~Hz}, 1 \mathrm{H}, 7-\mathrm{H}), 1.66$ (dqd, $J=14.0,7.3,3.0 \mathrm{~Hz}, 1 \mathrm{H}, 14-\mathrm{H}), 1.95(\mathrm{dd}, J=14.7,3.1 \mathrm{~Hz}, 1 \mathrm{H}$, 7-H), 2.02 (d, $J=1.4 \mathrm{~Hz}, 3 \mathrm{H}, 10-\mathrm{Me}), 2.15-2.23$ (m, 1H, 4-H), 2.15-2.21 (m, 1H, 8-H), 2.65 (dq, $J=7.3 \mathrm{~Hz}, 1 \mathrm{H}, 2-\mathrm{H}), 3.10$ (s, $3 \mathrm{H}, 6-\mathrm{OMe}$ ), 3.77 (dd, $J=7.4,3.4 \mathrm{~Hz}, 1 \mathrm{H}, 3-\mathrm{H}), 4.02$ (d, $J=$ $2.1 \mathrm{~Hz}, 1 \mathrm{H}, 5-\mathrm{H}), 4.97$ (dd, $J=11.5,2.8 \mathrm{~Hz}, 1 \mathrm{H}, 13-\mathrm{H}), 5.65$ (d, $J=1.4 \mathrm{~Hz}, 1 \mathrm{H}, 11-\mathrm{H}) ;{ }^{13} \mathrm{C} \mathrm{NMR}\left(75 \mathrm{MHz}, \mathrm{CDCl}_{3}\right) \delta 10.4(15-$ C), 14.0 (4-Me), 15.3 (8-Me), 16.3 (10-Me), 18.2 (2-Me), 21.4 (6-Me), 22.5 (12-Me), 24.4 (14-C), 32.1 (8-C), 36.4 (7-C), 41.9 (4-C), 46.3 (2-C), 48.3 (6-OMe), 74.3 (6-C), 78.8 (3-C), 78.9 (5-C), 79.0 (13-C), 88.9 (12-C), 112.1 (9-C), 131.2 (11-C), 138.8 (10-C), $174.0(1-\mathrm{C})$; HRMS: $[\mathrm{M}+\mathrm{H}]^{+}$measured 397.2586, calculated 397.2590, error $-1 \mathrm{ppm}$.

Compound 4: ${ }^{1} \mathrm{H}$ NMR $\left(600 \mathrm{MHz}, \mathrm{CDCl}_{3}\right) \delta 0.78(\mathrm{~d}$, $J=6.6 \mathrm{~Hz}, 3 \mathrm{H}, 8-\mathrm{Me}), 0.93(\mathrm{t}, J=7.3 \mathrm{~Hz}, 3 \mathrm{H}, 15-\mathrm{H}), 1.18$ (d, $J=7.7 \mathrm{~Hz}, 3 \mathrm{H}, 4-\mathrm{Me}), 1.24$ (s, 3H, 12-Me), 1.27 (d, $J=6.8 \mathrm{~Hz}$, $3 \mathrm{H}, 2-\mathrm{Me}), 1.40$ (s, 3H, 6-Me), 1.42 (ddq, $J=14.0,11.0$, $7.3 \mathrm{~Hz}, 1 \mathrm{H}, 14-\mathrm{H}), 1.61$ (dd, $J=12.4,4.0 \mathrm{~Hz}, 1 \mathrm{H}, 7-\mathrm{H}), 1.68$ (dqd, $J=14.0,7.3,2.4 \mathrm{~Hz}, 1 \mathrm{H}, 14-\mathrm{H}), 1.67-1.72(\mathrm{~m}, 1 \mathrm{H}, 7-\mathrm{H})$, $1.72(\mathrm{~d}, J=1.6 \mathrm{~Hz}, 3 \mathrm{H}, 10-\mathrm{Me}), 1.87(\mathrm{dqd}, J=13.3,6.7$, $4.2 \mathrm{~Hz}, 1 \mathrm{H}, 8-\mathrm{H}), 2.31$ (q, $J=7.1 \mathrm{~Hz}, 1 \mathrm{H}, 4-\mathrm{H}), 2.89$ (dq, $J=7.5 \mathrm{~Hz}, 1 \mathrm{H}, 2-\mathrm{H}), 3.21$ (s, 3H, 6-OMe), 3.77 (dd, $J=7.4$, $3.4 \mathrm{~Hz}, 1 \mathrm{H}, 3-\mathrm{H}), 4.24$ (br. s., $1 \mathrm{H}, 5-\mathrm{H}), 4.77$ (dd, $J=11.3,2.5$ $\mathrm{Hz}, 1 \mathrm{H}, 13-\mathrm{H}), 5.53(\mathrm{~d}, \mathrm{~J}=1.4,1 \mathrm{H}, 11-\mathrm{H}) ;{ }^{13} \mathrm{C}$ NMR $(75 \mathrm{MHz}$, $\left.\mathrm{CDCl}_{3}\right) \delta 10.8$ (15-C), 11.7 (10-Me), 14.7 (4-Me), 17.4 (2-Me), 17.5 (8-Me), 22.8 (12-Me), 24.1 (14-C), 24.8 (6-Me), 31.8 (8-C), 34.1 (7-C), 41.6 (4-C), 43.3 (2-C), 48.9 (6-OMe), 73.3 (6-C), 78.9 (13-C), 79.6 (3-C, 5-C), 89.6 (12-C), 111.1 (9-C), 125.7 (11-C), 139.6 (10-C), 176.1 (1-C); ${ }^{1} \mathrm{H}$ NMR (600 MHz, DMSO- $\left.d_{6}\right) \delta 0.71(\mathrm{~d}, J=6.6 \mathrm{~Hz}, 3 \mathrm{H}, 8-\mathrm{Me}), 0.80(\mathrm{t}, J=7.3 \mathrm{~Hz}$, $3 \mathrm{H}, 15-\mathrm{H}), 1.01$ (d, $J=7.9 \mathrm{~Hz}, 3 \mathrm{H}, 4-\mathrm{Me}), 1.09$ (d, $J=6.8 \mathrm{~Hz}$, $3 \mathrm{H}, 2-\mathrm{Me}$ ), 1.18 (s, 3H, 12-Me), 1.33 (s, 3H, 6-Me), 1.35 (ddq, $J=14.5,11.3,7.2 \mathrm{~Hz}, 1 \mathrm{H}, 14-\mathrm{H}), 1.50(\mathrm{dd}, J=12.7 \mathrm{~Hz}, 1 \mathrm{H}$, 7-H), $1.62(\mathrm{dd}, J=12.0,3.7 \mathrm{~Hz}, 1 \mathrm{H}, 7-\mathrm{H}), 1.67$ (dqd, $J=14.0$, 7.5, 2.4 Hz, 1H, 14-H), 1.66 (d, $J=1.6 \mathrm{~Hz}, 3 \mathrm{H}, 10-\mathrm{Me}), 1.86$ (dqd, $J=13.4,6.6,3.8 \mathrm{~Hz}, 1 \mathrm{H}, 8-\mathrm{H}), 2.18$ (qdd, $J=7.8,3.0,2.0$ $\mathrm{Hz}, 1 \mathrm{H}, 4-\mathrm{H}), 2.63$ (dq, $J=10.3,6.8 \mathrm{~Hz}, 1 \mathrm{H}, 2-\mathrm{H}), 3.12$ (s, 3H, 6-OMe), 3.37-3.40 (m, 1H, 3-H), 4.17 (s, 1H, 5-H), 4.59 (dd, $J$ $=11.3,2.4 \mathrm{~Hz}, 1 \mathrm{H}, 13-\mathrm{H}), 4.87$ (br. s., $1 \mathrm{H}, 3-\mathrm{OH}), 5.66$ (q, $J=1.4 \mathrm{~Hz}, 1 \mathrm{H}, 11-\mathrm{H}) \mathrm{ppm} ;{ }^{13} \mathrm{C}$ NMR $\left(151 \mathrm{MHz}, \mathrm{DMSO}-d_{6}\right) \delta$ 10.6 (15-C), 11.4 (10-Me), 14.7 (4-Me), 17.3 (8-Me), 17.5 (2-Me), 22.5 (12-Me), 23.3 (14-C), 24.4 (6-Me), 31.2 (8-C), 33.7 (7-C), 40.6 (4-C), 42.7 (2-C), 48.5 (6-OMe), 72.7 (6-C), 77.6 (3-C), 78.2 (13-C), 79.0 (5-C), 89.3 (12-C), 110.5 (9-C), 126.0 (11-C), 138.3 (10-C), 175.6 (1-C) ppm; HRMS: $[\mathrm{M}+\mathrm{H}]^{+}$ measured 397.2588 , calculated 397.2590 , error $-0.5 \mathrm{ppm}$

\section{Supporting Information}

\section{Supporting Information File 1}

Observed nOe contacts (Tables SI1-4), proton vicinal coupling constants used for molecular modelling calculations (Table SI5) and accurate mass measurements (Table SI7) for compounds 2-4, as well as HRMS fragmentation for compound $\mathbf{2}$ (Figures SI1 and SI2, Table SI6). Details of the reaction kinetics calculation. [http://www.beilstein-journals.org/bjoc/content/ supplementary/1860-5397-11-157-S1.pdf]

\section{Supporting Information File 2}

Results of molecular modelling for compounds 2-4 in mol2 format.

[http://www.beilstein-journals.org/bjoc/content/ supplementary/1860-5397-11-157-S2.zip]

\section{Supporting Information File 3}

NMR spectra of compounds $\mathbf{2}-\mathbf{4}$.

[http://www.beilstein-journals.org/bjoc/content/ supplementary/1860-5397-11-157-S3.zip] 


\section{Acknowledgements}

The authors would like to thank Danijel Namjesnik and Prof. Davor Kovačević for assistance with the kinetics calculations and Prof. Vitomir Šunjić for fruitful discussions and comments.

\section{References}

1. Mutak, S. J. Antibiot. 2007, 60, 85-122. doi:10.1038/ja.2007.10

2. Djokić, S.; Kobrehel, G.; Lopotar, N.; Kamenar, B.; Nagl, A.; Mrvoš, D. J. Chem. Res., Synop. 1988, 152-153.

3. Djokić, S.; Kobrehel, G.; Lazarevski, G.; Lopotar, N.; Tamburašev, Z.; Kamenar, B.; Nagl, A.; Vicković, I. J. Chem. Soc., Perkin Trans. 1 1986, 1881-1890. doi:10.1039/p19860001881

4. Morimoto, S.; Takahashi, Y.; Watanabe, Y.; Omura, S. J. Antibiot. 1984, 37, 187-189. doi:10.7164/antibiotics.37.187

5. Čulić, O.; Eraković, V.; Parnham, M. J. Eur. J. Pharmacol. 2001, 429, 209-229. doi:10.1016/S0014-2999(01)01321-8

6. Shinkai, M.; Henke, M. O.; Rubin, B. K. Pharmacol. Ther. 2008, 117, 393-405. doi:10.1016/j.pharmthera.2007.11.001

7. Alzolibani, A. A.; Zedan, K. Mediators Inflammation 2012, No. 159354. doi:10.1155/2012/159354

8. Kwiatkowska, B.; Maślińska, M. Mediators Inflammation 2012, No. 636157. doi:10.1155/2012/636157

9. Ogrendik, M. Int. J. Gen. Med. 2014, 43-47. doi:10.2147/IJGM.S56957

10. Wong, E. H. C.; Porter, J. D.; Edwards, M. R.; Johnston, S. L. Lancet Respir. Med. 2014, 2, 657-670. doi:10.1016/S2213-2600(14)70107-9

11. Mikasa, K.; Sawaki, M.; Kita, E.; Hamada, K.; Teramoto, S.; Sakamoto, M.; Maeda, K.; Konishi, M.; Narita, N. Chemotherapy 1997, 43, 288-296. doi:10.1159/000239580

12. Hamada, K.; Mikasa, K.; Yunou, Y.; Kurioka, T.; Majima, T.; Narita, N.; Kita, E. Chemotherapy 2000, 46, 49-61. doi:10.1159/000007256

13. Altman, J. K.; Platanias, L. C. Leuk. Lymphoma 2012, 53, 1255-1256. doi:10.3109/10428194.2012.661857

14. Andersen, S. L.; Oloo, A. J.; Gordon, D. M.; Ragama, O. B.; Aleman, G. M.; Berman, J. D.; Tang, D. B.; Dunne, M. W.; Shanks, G. D. Clin. Infect. Dis. 1998, 26, 146-150. doi:10.1086/516281

15. Taylor, W. R. J.; Richie, T. L.; Fryauff, D. J.; Picarima, H.; Ohrt, C.; Tang, D.; Braitman, D.; Murphy, G. S.; Widjaja, H.; Tjitra, E.; Ganjar, A.; Jones, T. R.; Basri, H.; Berman, J. Clin. Infect. Dis. 1999, 28, 74-81. doi:10.1086/515071

16. Perron, F.; Albizati, K. F. Chem. Rev. 1989, 89, 1617-1661. doi:10.1021/cr00097a015

17. Mead, K. T.; Brewer, B. N. Curr. Org. Chem. 2003, 7, 227-256. doi:10.2174/1385272033372969

18. Sheppeck, J. E., II; Gauss, C.-M.; Chamberlin, A. R. Bioorg. Med. Chem. 1997, 5, 1739-1750. doi:10.1016/S0968-0896(97)00146-6

19. Lindvall, M. K.; Pihko, P. M.; Koskinen, A. M. P.; Chem, C. F. B. J. B. Biochemistry 1997, 272, 23312-23316.

20. Pettit, G. R.; Inoue, M.; Kamano, Y.; Herald, D. L.; Arm, C.; Dufresne, C.; Christie, N. D.; Schmidt, J. M.; Doubek, D. L.; Krupa, T. S. J. Am. Chem. Soc. 1988, 110, 2006-2007. doi:10.1021/ja00214a078

21. Xu, Q.; Huang, K.-C.; Tendyke, K.; Marsh, J.; Liu, J.; Qiu, D.; Littlefield, B. A.; Nomoto, K.; Atasoylu, O.; Risatti, C. A.; Sperry, J. B.; Smith, A. B. I. Anticancer Res. 2011, 31, 2773-2780.

22. Lorente, A.; Makowski, K.; Albericio, F. Ann. Mar. Biol. Res. 2014, 1, 1003-1013.
23. Aho, J. E.; Pihko, P. M.; Rissa, T. K. Chem. Rev. 2006, 105, 4406-4440. doi:10.1021/cr050559n

24. Koshino, H.; Takahashi, H.; Osada, H.; Isono, K. J. Antibiot. 1992, 45, 1420-1427. doi:10.7164/antibiotics.45.1420

25. Sato, S.; Iwata, F.; Yamada, S.; Katayama, M. J. Nat. Prod. 2012, 75, 1974-1982. doi:10.1021/np300719g

26. Tsukamoto, Y.; Kajino, H.; Sato, K.; Tanaka, K.; Yanai, T. Biosci., Biotechnol., Biochem. 1997, 61, 806-812. doi:10.1271/bbb.61.806

27. Singh, S. B.; Zink, D. L.; Heimbach, B.; Genilloud, O.; Teran, A.; Silverman, K. C.; Lingham, R. B.; Felock, P.; Hazuda, D. J. Org. Lett. 2002, 4, 1123-1124. doi:10.1021/ol025539b

28. Munday, R. Toxins 2013, 5, 267-285. doi:10.3390/toxins5020267

29. Gerber-Lemaire, S.; Vogel, P. C. R. Chim. 2008, 11, 1382-1418. doi:10.1016/j.crci.2008.04.016

30. Ueno, T.; Takahashi, H.; Oda, M.; Mizunuma, M.; Yokoyama, A.; Goto, Y.; Mizushina, Y.; Sakaguchi, K.; Hayashi, H. Biochemistry 2000, 39, 5995-6025. doi:10.1021/bi992661i

31. Uckun, F. M.; Mao, C.; Vassilev, A. O.; Huang, H.; Jan, S.-T. Bioorg. Med. Chem. Lett. 2000, 10, 541-545. doi:10.1016/S0960-894X(00)00044-5

32. Alihodžić, S.; Fajdetić, A.; Kobrehel, G.; Lazarevski, G.; Mutak, S.; Pavlović, D.; Štimac, V.; Čipčić, H.; Dominis Kramarić, M.; Eraković, V.; Hasenohrl, A.; Maršić, N.; Schoenfeld, W. J. Antibiot. 2006, 59, 753-769. doi:10.1038/ja.2006.100

33. Fajdetić, A.; Vinter, A.; Paljetak, H. Č.; Padovan, J.; Jakopović, I. P.; Kapić, S.; Alihodžić, S.; Filić, D.; Modrić, M.; Košutić-Hulita, N.; Antolović, R.; Schoenfeld, Z. I.; Mutak, S.; Haber, V. E.; Spaventi, R. Eur. J. Med. Chem. 2011, 46, 3388-3397. doi:10.1016/j.ejmech.2011.05.002

34. Kapić, S.; Fajdetić, A.; Koštrun, S.; Čikoš, A.; Paljetak, H. Č.; Antolović, R.; Holmes, D. J.; Alihodžić, S. Bioorg. Med. Chem. 2011, 19, 7270-7280. doi:10.1016/j.bmc.2011.07.011

35. Starčević, K.; Pešić, D.; Toplak, A.; Landek, G.; Alihodžić, S.; Herreros, E.; Ferrer, S.; Spaventi, R.; Perić, M. Eur. J. Med. Chem. 2012, 49, 365-378. doi:10.1016/j.ejmech.2012.01.039

36. Tomašković, L.; Komac, M.; Makaruha Stegić, O.; Munić, V.; Ralić, J.; Stanić, B.; Banjanac, M.; Marković, S.; Hrvačić, B.; Čipčić Paljetak, H.; Padovan, J.; Glojnarić, I.; Eraković Haber, V.; Mesić, M.; Merćep, M. Bioorg. Med. Chem. 2013, 21, 321-332. doi:10.1016/j.bmc.2012.10.036

37. Nujić, K.; Smith, M.; Lee, M.; Belamarić, D.; Tomašković, L.; Alihodžić, S.; Malnar, I.; Polančec, D.; Schneider, K.; Haber, V. E. Eur. J. Pharmacol. 2012, 677, 163-172. doi:10.1016/j.ejphar.2011.12.022

38. Bosnar, M.; Kragol, G.; Koštrun, S.; Vujasinović, I.; Bošnjak, B.; Mihaljević, V. B.; Ištuk, Z. M.; Kapić, S.; Hrvačić, B.; Brajša, C.; Tavčar, B.; Jelić, D.; Glojnarić, I.; Verbanac, D.; Čulić, O.; Padovan, J.; Alihodžić, S.; Eraković Haber, V.; Spaventi, R. J. Med. Chem. 2012, 55, 6111-6123. doi:10.1021/jm300356u

39. Ćaleta, I.; Čikoš, A.; Žiher, D.; Đilović, I.; Dukši, M.; Gembarovski, D.; Grgičević, I.; Krajačić, M. B.; Filić, D.; Matković-Čalogović, D.; Malnar, I.; Alihodžić, S. Struct. Chem. 2012, 23, 1785-1796. doi:10.1007/s11224-012-9984-3

40. Flynn, E. H.; Sigal, M. V., Jr.; Wiley, P. F.; Gerzon, K. J. Am. Chem. Soc. 1954, 76, 3121-3131. doi:10.1021/ja01641a005

41. Kurath, P.; Jones, P. H.; Egan, R. S.; Perun, T. J. Experientia 1971, 27, 362. doi:10.1007/BF02137246

42. Hassanzadeh, A.; Helliwell, M.; Barber, J. Org. Biomol. Chem. 2006, 4, 1014-1019. doi:10.1039/b518182h 
43. Atkins, P. J.; Herbert, T. O.; Jones, N. B. Int. J. Pharm. 1986, 30, 199-207. doi:10.1016/0378-5173(86)90079-7

44. Cachet, T.; Van den Mooter, G.; Hauchecorne, R.; Vinckier, C.; Hoogmartens, J. Int. J. Pharm. 1989, 55, 59-65. doi:10.1016/0378-5173(89)90277-9

45. Vinckier, C.; Hauchecorne, R.; Cachet, T.; Van den Mooter, G.; Hoogmartens, J. Int. J. Pharm. 1989, 55, 67-76. doi:10.1016/0378-5173(89)90278-0

46. Kim, Y.-H.; Heinze, T. M.; Beger, R.; Pothuluri, J. V.; Cerniglia, C. E. Int. J. Pharm. 2004, 271, 63-76. doi:10.1016/j.ijpharm.2003.10.023

47. Hassanzadeh, A.; Barber, J.; Morris, G. A.; Gorry, P. A. J. Phys. Chem. A 2007, 111, 10098-10104. doi:10.1021/jp073030y

48. Nakagawa, Y.; Itai, S.; Yoshida, T.; Nagai, T. Chem. Pharm. Bull. 1992, 40, 725-728. doi:10.1248/cpb.40.725

49. Morimoto, S.; Misawa, Y.; Asaka, T.; Kondoh, H.; Watanabe, Y. J. Antibiot. 1990, 43, 570-573. doi:10.7164/antibiotics.43.570

50. Mordi, M. N.; Pelta, M. D.; Boote, V.; Morris, G. A.; Barber, J. J. Med. Chem. 2000, 43, 467-474. doi:10.1021/jm9904811

51. O’Donnell, T.; Brook Knight, M.; McArthur, H. A. I.; Dirlam, J. P. EP1024145A2 2000, 36.

52. Huang, S.-X.; Zhao, L.-X.; Tang, S.-K.; Jiang, C.-L.; Duan, Y.; Shen, B. Org. Lett. 2009, 11, 1353-1356. doi:10.1021/ol900143j

53. Kao, C.-L.; Borisova, S. A.; Kim, H. J.; Liu, H.-w. J. Am. Chem. Soc. 2006, 128, 5606-5607. doi:10.1021/ja058433v

54. Auricchio, S.; Fronza, G.; Mele, A.; Favara, D. J. Org. Chem. 1992, 57, 452-455. doi:10.1021/jo00028a014

55. Schomburg, D.; Hopkins, P. B.; Lipscomb, W. N.; Corey, E. J. J. Org. Chem. 1980, 45, 1544-1546. doi:10.1021/jo01296a051

56. Muri, D.; Carreira, E. M. J. Org. Chem. 2009, 74, 8695-8712. doi:10.1021/jo901817b

57. Kibwage, I. O.; Busson, R.; Janssen, G.; Hoogmartens, J.; Vanderhaeghe, H.; Brake, J. J. Org. Chem. 1987, 52, 990-996. doi:10.1021/jo00382a004

58. Grover, R. K.; Joshi, B. S.; Batra, S.; Roy, R.; Bhaduri, A. P. Magn. Reson. Chem. 2001, 39, 355-360. doi:10.1002/mrc.858

59. For presentation of the conformation of the tetrahydropyran rings in the presented spiroketals we adopted the IUPAC recommendations for nomenclature of carbohydrates:

http://www.chem.qmul.ac.uk/iupac/2carb/06n07.html\#07. For all three spiroketals (2, 3 and 4) 6-C, 7-C, 9-C, 5-O form the reference plane of the chair conformation (" $C$ "), while $5-C$ and $8-C$ are exoplanar atoms. Thus the tetrahydropyran ring in compounds 2 and $\mathbf{3}$ is in ${ }^{5} C_{8}$ conformation, while in 4 it is in ${ }^{8} C_{5}$. Eur. J. Biochem. / FEBS 1980, 111, 295-298.

60. Zinzalla, G.; Milroy, L.-G.; Ley, S. V. Org. Biomol. Chem. 2006, 4, 1977-2002. doi:10.1039/b603015g

61. Bamford, C. H.; Tipper, C. F. H., Eds. The theory of kinetics, 1st ed.; Comprehensive Chemical Kinetics, Vol. 2; Elsevier Scientific Publishing: Amsterdam, Netherlands, 1969. doi:10.1016/B978-0-444-40674-3.50006-7

62. Perun, T. J. J. Org. Chem. 1967, 32, 2324-2330. doi:10.1021/jo01282a051

63. Gunnes, S.; Rømming, C.; Undheim, K. Tetrahedron 2006, 62, 6090-6099. doi:10.1016/j.tet.2006.03.098

64. Stepanić, V.; Koštrun, S.; Malnar, I.; Hlevnjak, M.; Butković, K.; Ćaleta, I.; Dukši, M.; Kragol, G.; Makaruha-Stegić, O.; Mikac, L.; Ralić, J.; Tatić, I.; Tavčar, B.; Valko, K.; Zulfikari, S.; Munić, V. J. Med. Chem. 2011, 54, 719-733. doi:10.1021/jm101317f

65. Maestro, Version 10.1, Schrödinger Release 2015-1; Schrödinger LLC: New York, NY, U.S.A., 2015.

\section{License and Terms}

This is an Open Access article under the terms of the Creative Commons Attribution License

(http://creativecommons.org/licenses/by/2.0), which permits unrestricted use, distribution, and reproduction in any medium, provided the original work is properly cited.

The license is subject to the Beilstein Journal of Organic Chemistry terms and conditions:

(http://www.beilstein-journals.org/bjoc)

The definitive version of this article is the electronic one which can be found at:

doi:10.3762/bjoc. 11.157 